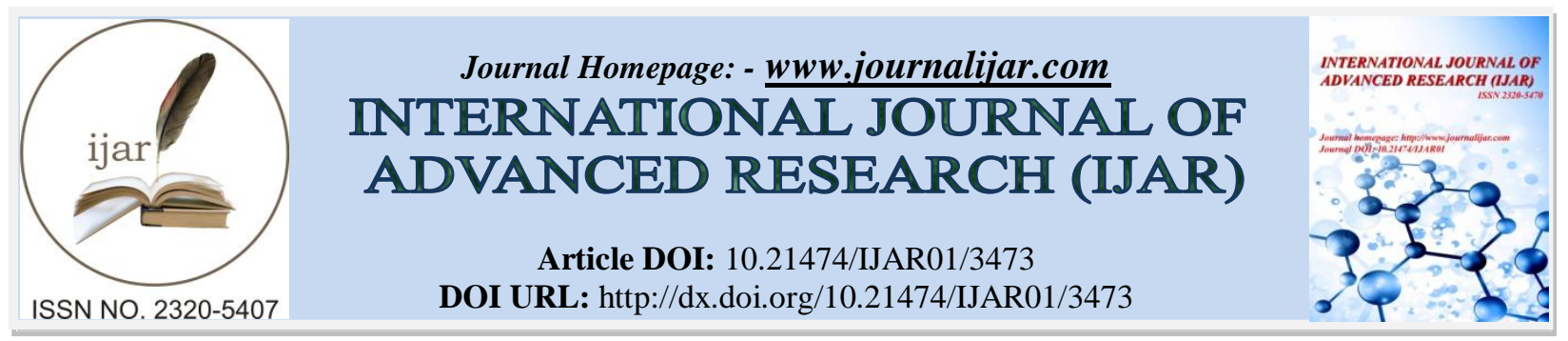

RESEARCH ARTICLE

\title{
A STUDY ON 3-BODY ABRASIVE WEAR BEHAVIOUR OF ALUMINIUM
}

Rahul Singh Nhce Bangalore.

\section{Manuscript Info}

\section{Manuscript History}

Received: 20 December 2016

Final Accepted: 20 January 2017

Published: February 2017

\begin{abstract}
Metals and alloys have found their many role in many applications like structural and corrosive, environment. The alloys/composites having high strength to low weight ratio have gained attention of many researchers. In the above work, Aluminium metal matrix composite was prepared by die casting route, by varying the weight \% of reinforcement. Made composite specimens are subjected to 3-body abrasive testing by varying applied load and time, the epoxy particles of 900 grit size were used as abrasive particles. It was observed that with increase of weight of wear resistance of composite was also increasing and on comparison it was found reinforced composite gives good wear resistance to the base alloy.
\end{abstract}

Copy Right, IJAR, 2017,. All rights reserved.

\section{Introduction:-}

Since last two decades, composite materials have attracted researchers than their counterpart Monolithic materials due to ability to alter their physical properties and mechanical properties by varying filler phase. Based on type of matrix phase, composite are divided into metal matrix (MMC), polymer matrix (PMC), ceramic matrix composites (CMC) . MMCs have good strength, thermal conductivity, damping properties, low coefficient of thermal expansion and lower density. For these reasons it is preferred in tribological applications.

\section{Experimental Procedure:-}

\section{Material:-}

In this work, as already mentioned, Aluminium alloy was used as metal matrix composite. In this alloy, magnesium has poor alloying element, hence magnesium was used as wetting agent for proper mixing. The chemical composition and mechanical properties are given in table 1and 2[13].

Table 1:- Chemical Composition of Al 8011

\begin{tabular}{|l|l|l|l|l|l|l|l|l|l|}
\hline Material & $\mathrm{Fe}$ & $\mathrm{Si}$ & $\mathrm{Mn}$ & $\mathrm{Zn}$ & $\mathrm{Cu}$ & $\mathrm{Ti}$ & $\mathrm{Cr}$ & $\mathrm{Mg}$ & $\mathrm{Al}$ \\
\hline Weight $\%$ & 1 & 0.8 & 0.2 & 0.1 & 0.1 & 0.06 & 0.05 & 0.04 & 97.5 \\
\hline
\end{tabular}

Table 2:- Mechanical Properties of Al 8011

\begin{tabular}{|l|l|l|l|l|}
\hline Density & Elastic Modulus & $\begin{array}{l}\text { Strength to } \\
\text { Weight Ratio }\end{array}$ & $\begin{array}{l}\text { Ultimate Tensile } \\
\text { Strength }\end{array}$ & $\begin{array}{l}\text { Thermal } \\
\text { Expansion }\end{array}$ \\
\hline $2.72 \mathrm{~g} / \mathrm{cm}^{3}$ & $91 \mathrm{GPa}$ & $50 \mathrm{kN}-\mathrm{m} / \mathrm{kg}$ & $110 \mathrm{Mpa}$ & $31.8 \mu \mathrm{m} / \mathrm{m}-\mathrm{k}$ \\
\hline
\end{tabular}




\section{Reinforcement:-}

Graphite powder of an average size of 50 microns were used as reinforcement, Graphite powder has physical properties like good electrical and thermal conductivity, high purity, and temperature stability. Graphite is a well-recognized solid lubricant which also has the advantage of low density. In graphite reinforced Aluminium Matrix Composites (AMCs), Graphite serves as a solid lubricating layer between the composite and rubbing surface helping in reduction of composite wear and does not need any additional solid and liquid lubrication [14].

\section{Composite preparation:-}

The Al-cr composite was fabricated by two step mixing stir casting method, stirring speed was gradually increased up to 600rpm and it was done for about 500sec. When compared to conventional stirring, double stir casting results in more uniform microstructure. The Al 8011 alloy ingots, were cut into small pieces using hand press, placed in graphite crucible and heated in a resistance furnace up to $750^{0} \mathrm{C}$ above its melting point $\left(860^{\circ} \mathrm{C}\right)$, the maximum temperature level of furnace being $1200^{\circ} \mathrm{C}$.

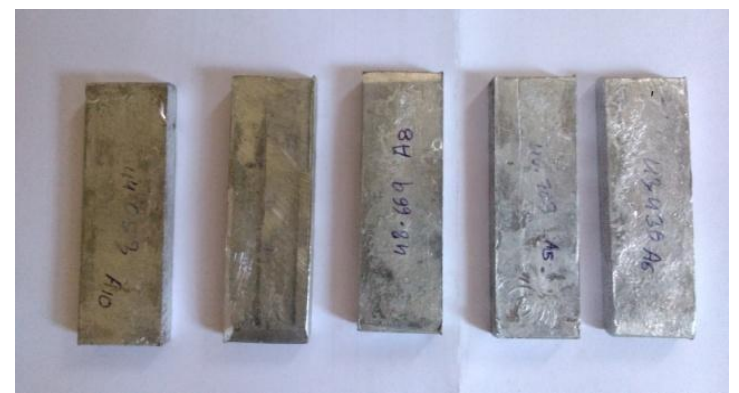

Figure 1 a:- Specimens before wear test.

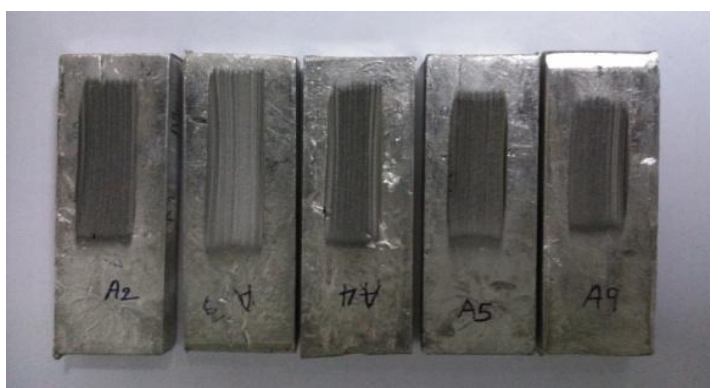

Figure 1 b:- Specimens after wear test.

\section{Result and Discussion:-}

In 2-body abrasion process, particles are rigidly attached to the second body, where as in 3-body abrasion process, wear is caused by loose abrasive particles which can freely move between contact surfaces. The wear rate in the three-body abrasion is lower when compared two-body abrasion [16]. The results of 3-body abrasive wear test for various combinations of applied load and time were tabulated.

\section{Microstructure:-}

Figure 2(a) shows optical micrograph of $\mathrm{Al}$ alloy 8011 with $2 \%$ reinforcement, at 30 magnification scale. Similarly figures 2(b), 2(c) and 2(d) show micrographs of 4\%,6\% and 8\% reinforcement in $\mathrm{Al}$ alloy 8011 respectively. The microstructures show that uniform distribution of graphite particles throughout the aluminium alloy. This indicates that there is good bonding between the alloy and reinforcement particles resulting in good wear resistance.

\section{Conclusion:-}

3-Body Abrasive wear behaviour of $\mathrm{Al}$ was studied in this work.

The samples were subjected to wear test by varying the load in the range of 10-40 kgs for various durations of time at constant speed of $600 \mathrm{rpm}$. From the experimental investigation following main conclusions are drawn: 
Successful fabrication of 8011 Aluminum composite reinforced with cu is possible by simple two- step stir casting process.

On comparison it is found that reinforced composite gives good 3-D wear resistance than base $\mathrm{Al}$ alloy.

\section{Reference:-}

1. Himanshu Kala, K.K.S Mer and Sandeep Kumar A review on mechanical and tribological behaviours of stir cast aluminium matrix composites 2014 procedia Material Science 6 1951- 1960.

2. www.azom. com/article.aspx?ArticleID=8782. 